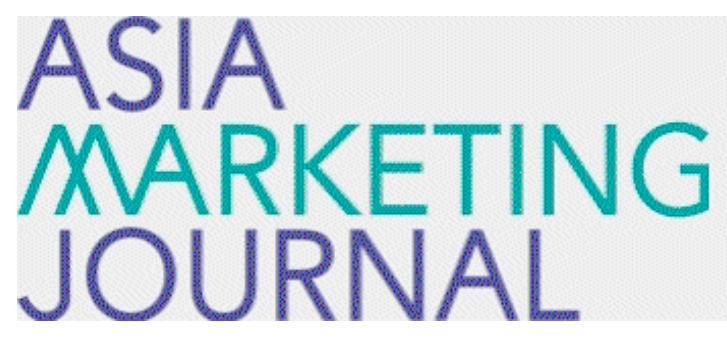

ASIA MARKETING JOURNAL

Volume 22 | Issue 3

Article 1

$10-31-2020$

\title{
Impact of Negative Word of Mouth on Firm Value
}

Jaihyun Jeon

Byung-Do Kim

Junhee Seok

Follow this and additional works at: https://amj.kma.re.kr/journal

Part of the Marketing Commons

\section{Recommended Citation}

Jeon, Jaihyun; Kim, Byung-Do; and Seok, Junhee (2020) "Impact of Negative Word of Mouth on Firm Value," Asia Marketing Journal: Vol. 22 : Iss. 3 , Article 1.

Available at: https://doi.org/10.15830/amj.2020.22.3.1

This Article is brought to you for free and open access by Asia Marketing Journal. It has been accepted for inclusion in Asia Marketing Journal by an authorized editor of Asia Marketing Journal. 


\title{
Impact of Negative Word of Mouth on Firm Value*
}

\author{
Jaihyun Jeon** \\ Byung-Do Kim*** \\ Junhee Seok ${ }^{* * * *}$
}

\begin{abstract}
With the development of information and communication technology and spread of smart devices, online information exchange has become a daily routine. Accordingly, the management and utilization of online word of mouth (WOM) has become an important issue for companies. Numerous studies have examined the impact of online WOM on firm performance. This study analyzes the impact of negative word of mouth (NWOM) on firm value, considering the influence of corporate social responsibility (CSR) activity and research and development (R\&D) investment. Using a hierarchical linear model, we find that 1) NWOM has a negative impact on firm value, 2) CSR activities do not significantly influence this impact, and 3) R\&D investment reduces this negative impact.

This study contributes by demonstrating the effect of NWOM on firm value, examining the influence of CSR activities and R\&D investment on the impact of NWOM, and confirming that the hierarchical linear model can be applied effectively to panel data in empirical studies. As a practical implication, companies must prevent and manage NWOM, whose impact, when caused by an unavoidable incident, can be alleviated by proactively announcing that the company is striving for competitiveness, for instance, by investing in R\&D.
\end{abstract}

Keywords: Word of mouth, negative word of mouth, firm value, CSR, R\&D

\section{Introduction}

With the proliferation of mobile devices and high-speed Internet, people can access social media platforms anytime, anywhere. This makes it easier for consumers to listen to other consumers and share their opinions. As such,

\footnotetext{
This study was supported by the Institute of Management Research at Seoul National University.

** Intern, Johnson \& Johnson Consumer, Seoul, Korea (jaihyun92@gmail.com), First Author

*** Professor, College of Business Administration, Seoul National University, Seoul, Korea (bxk@snu.ac.kr)

**** Ph.D. student, College of Business Administration, Seoul National University, Seoul, Korea (boss825@snu.ac.kr), Corresponding Author
} 
companies look for various ways to listen to and manage the Voice of the Customers (VOC). Abundant research exists on online word of mouth (WOM), whose components can be divided into volume and valence. Volume refers to the total amount of WOM and valence represents the emotional aspects, positive or negative (Liu 2006). In addition, some studies of WOM have divided it into positive word of mouth (PWOM) and negative word of mouth (NWOM). According to Lee (2019), satisfied customers share their experience with eight people, while dissatisfied customers share it with 25 people. The spread of NWOM is thus far faster than that of PWOM and has a greater impact on firm performance (Chevalier and Mayzlin 2006). Therefore, companies must put a lot of effort into curbing and managing NWOM.

This study mainly addresses the effect of NWOM on firm value motivated by our curiosity about the impact of NWOM being influenced by external factors or the company's efforts. Said differently, although NWOM affects firm value, its impact may vary depending on the company's situation or efforts (Laczniak, DeCarlo, and Ramaswami 2001; Van Hoye and Lievens 2007). We focus on two factors: corporate social responsibility (CSR) activity and research and development (R\&D) investment. In addition, we examine the possibility of linking CSR activities and R\&D investment with the stereotype content model (SCM). SCM theory suggests that people judge other individuals or groups based on two fundamental dimensions: warmth and competence (Cuddy, Fiske, and Glick 2008; Cuddy, Glick, and Beninger 2011; Durante, Volpato, and Fiske 2010; Fiske, Cuddy, and Glick 2007; Li, Chan, and Kim 2019). Since the SCM is known to be applicable to various social objects, not only people but also companies (Fournier 1998), we introduce the SCM in this study.

As a result of the analysis, we find that NWOM has a negative effect on firm value. According to prior studies, NWOM negatively affects firm value by reducing intangible assets such as customer and brand equity (BambauerSachse and Mangold 2011; Luo 2009; Srivastaba, Shervani, and Fahey 1998). Between CSR activities and $R \& D$ investment, only $R \& D$ investment is shown to reduce the negative impact of NWOM. Meanwhile, the role of CSR activities is not found to be significant because stakeholders detect corporate hypocrisy when facing a firm's NWOM and CSR simultaneously. Compared with existing research, this study has several distinct features. First, the effect of NWOM on firm value is analyzed for a relatively long span of time with real-world data. According to Luo (2009), few studies have verified the effect of WOM on firms' stock prices using existing data. We analyze the impact of NWOM on 71 Korean companies using weekly data for five years. Second, this study shows that the hierarchical linear model (HLM) is well suited for studies using panel data (Byun, 
Kim, and Nam 2013). Using the HLM as an estimation method, we examine the impact of NWOM on each company (rather than examining all firms as a whole) and discuss how that impact depends on the company's CSR activities and R\&D investment. Third, introducing the concept of the SCM, we raise the possibility of implementing the SCM on firms' features. We assume that CSR activities and R\&D investment are related to warmth and competence and show that the negative effects of NWOM may be influenced by the company's competence, that is, by the company's efforts.

The rest of this paper proceeds with a literature review in Section 2, outlining the major work related to NWOM, CSR activities, and R\&D investment. In Section 3, we present our key variables and estimation methods. We then present our empirical findings in Section 4. Lastly, we discuss our conclusion and the several implications and limitations of the study in Section 5 .

\section{Theoretical Background and Hypothesis Development}

\subsection{Online WOM}

WOM refers to the exchange of information about a product or service between consumers (Liu 2006). With the development of science and technology, the term "online word of mouth" emerged as consumers were provided with online space in which they could share their opinions (Jeon et al. 2019). WOM is known to have two main characteristics, namely, volume and valence (Mahajan, Muller, and Kerin 1984; Neelamegham and Jain, 1999). According to Liu (2006), volume indicates the total amount of WOM and valence is captured by the nature of WOM messages, as determined by the emotions behind words such as positivity and negativity. Various online WOM studies exist, especially of PWOM and NWOM (Babić Rosario et al. 2016). PWOM refers to a favorable experience or recommendation of a product, whereas NWOM implies sharing an unsatisfactory experience or negative content with others (Luo 2009). While PWOM is known to increase sales, brand awareness, and loyalty (Balqiah 2018: Kervyn, Fiske, and Malone 2012; Smith, Gradojevic, and Irwin 2007; Peterson and Jeong 2010), NWOM has a significant detrimental impact (Singh 1988). In addition, the effect of NWOM on reducing sales is greater than that of PWOM on increasing sales (Chevalier and Mayzlin 2006; Sun 2012). In short, online WOM has become common in everyday life and has been analyzed by largely dividing it into volume and valence, or PWOM and NWOM.

\subsection{Effect of NWOM on Firm Value}

Some studies have been conducted in the 
marketing field of the effects of NWOM. NWOM exerts a negative impact on brand evaluation, even though consumers may be aware and fond of the brand (Bambauer-Sachse and Mangold 2011). Luo (2009) analyzed the effect of NWOM on stock returns, with NWOM showing negative effects on stock prices in the short and long terms. Moreover, dissatisfied customers engage in NWOM, thereby causing a substantial negative impact on a firm's profitability (Blodgett and Li 2007). These findings reveal that NWOM has a negative impact on firm value. NWOM is known to decreases intangible assets such as customer and brand equity (Srivastaba, Shervani, and Fahey 1998). In addition, exposure to NWOM causes significant brand equity dilution since the brand value that consumers initially believed in is damaged by NWOM (Bambauer-Sachse and Mangold 2011). According to market-based asset theory, brand equity refers to the financial strength of a company in the stock market (Srivastava, Shervani, and Fahey 1998). In other words, NWOM reduces brand equity by damaging the value consumers place in the company, and since brand equity can be seen as a company's financial strength in the stock market, NWOM negatively affects stock returns. Further, since consumers' NWOM results from unsatisfactory experiences, companies with many incidences of NWOM lose loyal customers and future cash flows (Luo 2007). According to customer equity theory (Rust, Lemon, and Zeithaml 2004) and one customer lifetime value study (Gupta and Zeithaml 2006), NWOM leads to less robust future cash flows by decreasing customer repurchase intention and churning existing customers (Luo 2009). In this context, we assume that NWOM has a negative impact on firms. Accordingly, the first hypothesis is as follows.

\section{H1: As the negativity of WOM increases, firm value decreases.}

In brief, NWOM negatively affects firm value by affecting intangible assets such as customer equity, loyalty, and brand equity, which represent the financial strengths of a firm in the stock market. Furthermore, although NWOM may decrease firm value, it could be influenced by another factor. That is, the influence of NWOM on firm value may vary depending on various situations or efforts by the company (Laczniak, DeCarlo, and Ramaswami 2001; Van Hoye and Lievens 2007).

\subsection{The Role of CSR Activities and $\mathrm{R} \& \mathrm{D}$ Investment}

Society's expectations of companies are changing rapidly, and companies that cannot detect these social changes and focus only on traditional economic goals have become less secure (Kim 2016; Seok et al. 2017). According to Jones (1995), who explained companies' motivation to conduct CSR activities using instrumental 
theory, companies should act trustworthily and ethically to deal with stakeholders on the basis of trust and cooperation. In this case, the CSR attributes of a company, such as being honest, reliable, and ethical, are linked to the product and help the firm be perceived positively by consumers (Byun, Kim, and Nam 2013). Therefore, conducting CSR activities, companies can show their honest, trustworthy, and reliable image to consumers, thereby acquiring several benefits. Companies can gain competitive advantage by strengthening their social legitimacy through CSR activities and promoting their firm image to stakeholders (Handelman and Arnold 1999). A number of studies have shown that CSR activities have a positive effect on firm performance as well as on firm image. Moreover, CSR activities are known to increase performance and intangible assets such as purchase intention and reputation. CSR investments positively affect the purchase intention or reputation of a company (Carroll and Shabana 2010; Seok et al. 2017; Shea and Hawn 2019). Similarly, CSR activities increase not only reputation but also firm value (Pava and Krausz 1996; Schwartz and Carroll 2003; Seok et al. 2017; Servaes and Tamayo 2013). Moreover, CSR activities can enhance customer loyalty and play a major role in regaining loyalty, even after service failure occurs (Choi and La 2013; Martinez and Bosque 2013). In short, CSR activities increase intangible assets such as customer loyalty, reputation, and purchase intention and have a positive effect on a firm's overall performance.

This study considers R\&D investment as a second factor that could influence the impact of NWOM on firm value. To achieve long-term performance, companies must provide products and services that can deliver value to customers. Accordingly, companies invest in R\&D to meet customer needs (Byun, Kim, and Nam 2013). Owing to the importance of $R \& D$ investment, research on its impact on firm value has been conducted (Chakravarty and Grewal 2011; Eberhart, Maxwell, and Siddique 2004; Ho, Keh, and Ong 2005; Lin, Lee, and Hung 2006; Peterson and Jeong 2010; Seok, Kim, and Go 2019; Sridhar, Narayanan, and Srinivasan 2014). Excellent firm performance created from competitive advantage arises from excellent customer value creation capabilities, which can be achieved through R\&D investment (Mizik and Jacobson 2003). In addition, R\&D has been known to increase intangible assets such as brand equity and brand value. For example, Smith, Gradojevic, and Irwin (2007) showed that as R\&D investment increases, brand equity increases, and Peterson and Jeong (2010) argued that R\&D investment enhances brand value, which raises overall performance. Likewise, for companies that have a high proportion of R\&D investment, growth indicators tend to be higher than for those that do not (Del Monte and Papagni 2003). In sum, firms can gain competitive advantage by increasing intangible assets such as brand equity and brand value 
through R\&D investment.

In this study, we speculate that the role of $R \& D$ investment can be viewed from the perspective of SCM theory. SCM theory states that people judge different individuals and groups based on two fundamental dimensions: warmth and competence. Numerous studies have been conducted on this topic (Cuddy, Fiske, and Glick 2008; Cuddy, Glick, and Beninger 2011; Durante, Volpato, and Fiske 2010; Fiske, Cuddy, and Glick 2007; Li, Chan, and Kim 2019). Moreover, the SCM can be applied to various social objects, not only people but also companies, because it is similar to the relationships among people (Fournier 1998). From SCM theory, competence stands for intelligence, industriousness, practicality, power, efficacy, and skill (Cuddy, Glick, and Beninger 2011: Fiske, Xu, and Cuddy 1999), while the features of firm performance include quality, reliability, durability, and consistency (Kervyn, Fiske, and Maleone 2012). Meanwhile, some studies have argued that $R \& D$ expenditure can be taken as a proxy variable for technical competence because the accumulation of technological experience through $R \& D$ efforts contributes to the development of technological capacity (Kocoglu et al. 2012; Lee 2011). In addition, $R \& D$ improves skills and ability, which are the basis for innovation (Kocoglu et al. 2012), and R\&D is considered to be a suitable variable for technological competence (Lee 2011). Based on the logic of previous studies, we speculate that from the perspective of SCM theory, R\&D investment may be a factor in increasing a firm's competence. The more competent a company is, the more positively it affects brand attitude (Balqiah 2018). In addition, perceived competence positively affects consumer satisfaction, thereby increasing purchase intention and customer loyalty (Gao and Mattila 2014; Kervyn, Fiske, and Malone 2012). In brief, $R \& D$ investment can be seen as an aspect of the competence of a company that increases intangible assets such as brand attitude, purchase intention, and customer loyalty.

On the contrary, from the perspective of SCM theory, warmth is inferred from actions that appear to serve others' interest (Cuddy, Glick, and Beninger 2011), such that contributing to the welfare of others promotes warmth (Chen et al. 2020). Furthermore, CSR activities are a suitable variable for the warmth of a company because CSR activities tend to direct a firm's resources to the improvement of social welfare (Chen et al. 2020). Similarly, since CSR activities are firms' actions that imply warmth, they make consumers feel more warmth (Shea and Hawn 2019). In addition, in terms of SCM theory, warmth is said to be trustworthy and moral (Fiske et al. 2007), and because CSR has a trustworthy and moral property (Baron 2009), as in using the word "responsible," it is a suitable variable for warmth (Shea and Hawn 2019). Therefore, in this study, we conjecture that CSR activities increase the warmth of a 
company from the perspective of SCM theory. In sum, NWOM negatively affects a company's future cash flow and stock price by reducing intangible assets such as customer loyalty and brand equity (Luo 2009). Moreover, the impact of NWOM on firm value may be influenced by the various situations or efforts of the company (Laczniak, DeCarlo, and Ramaswami 2001; Van Hoye and Lievens 2007). Meanwhile, the company's CSR activities have a positive effect on intangible assets such as reputation, purchase intention, loyalty, and firm value and may also increase its warmth. Therefore, we expect that CSR activities can counteract the effect of NWOM, which reduces firm value by reducing intangible assets. Likewise, a company's R\&D investment has a positive effect on brand value, performance, and intangible assets and is the basis for a company's innovation. These characteristics may be considered to be related to competence from the SCM perspective, and since a company's competence is known to increase intangible assets such as purchase intention and brand attitude, this could help reduce the impact of NWOM. Accordingly, the next hypotheses are as follows.

H2: As CSR activities increase, the negative impact of NWOM on firm value decreases.

H3: As R\&D investment increases, the negative impact of NWOM on firm value decreases.

\section{Research Design}

\subsection{Variable Measurement and Sample Selection}

\subsubsection{Sample selection}

To test our hypotheses, we used financial and online WOM data on 71 Korean companies. The selection criteria for the 71 companies are as follows. Similar to the Fortune Company, an organization called Korea Management Association Consulting evaluates companies in Korea. Annually, it provides a list of Korea's Most Admired Company (KMAC). The KMAC report evaluates companies based on six core values: innovation capability, shareholders, employees, customers, social, image, and values. Furthermore, it indexes the ratings given by industry executives, financial analysts, and general consumers based on the abovementioned six core values. We selected companies listed in the KMAC report because to analyze the effect of online WOM, it is necessary to select companies with a certain degree of awareness among consumers. Companies listed in the KMAC report were selected based on their reputation, including the recognition of each industry group. A total of 77 companies were listed in the KMAC report from 2011 to 2015, and this study finally selected 71 companies whose financial variables were accessible.

We collected data from four sources. The 
first source is FnGuide, which provides firms' financial information such as stock prices, from which we calculated abnormal returns, as we discuss in the next section. The second source is the Korea Listed Companies Association (KLCA), which provides financial information such as donation amounts and R\&D. The third source is Statistics Korea. To measure the NWOM variable precisely, we gathered information on macroeconomic factors such as the unemployment rate, the consumer price index (CPI), and gross domestic product (GDP). The fourth source is a big data solution platform called Socialmetrics, managed by Daumsoft, one of the main search engines in Korea. When a certain keyword is entered in Socialmetrics, it gives not only the number of online WOM posts but also the number of positive, negative, neutral, and other types of words. As such, Socialmetrics enabled us to derive information on online WOM volume and valence (Jeon et al. 2019). The measures of these variables are discussed in detail in the next section.

\subsubsection{Measure of stock returns}

In this study, we measured stock returns as the firm's abnormal returns. Abnormal returns are changes in stock prices that cannot be explained by the average market portfolio returns and market-wide risk factors (Luo 2009). Following the literature (Luo 2009), we modeled stock returns based on the Fama-
French approach (Fama and French 1993; Fama and French 2006). The model is as follows:

$$
\begin{aligned}
S R_{i t}= & \gamma_{i}+\beta_{i M K T} M K T_{t}+\beta_{i H M L} H M L_{t} \\
& +\beta_{i S M B} S M B_{t}+\beta_{i U M D} U M D_{t} \\
& +\omega_{i t} \cdots \cdots \cdots \cdots \cdots \cdots \cdots \cdots \cdots \cdots \cdots \cdots \cdots \cdots \cdots \cdots \cdots
\end{aligned}
$$

where,

$S R_{i t}$ is the stock return in excess of the Treasury bill risk-free rate for firm $i$ at time $t$;

MKT is the excess market return;

$\mathrm{SMB}$ is a size-based risk premium factor;

HML is a book-to-market-based risk premium factor;

$\mathrm{UMB}$ is the return momentum factor; and $\omega$ is the residual.

Using Equation (1), we examined the relationship between stock returns, average market portfolios, and market-wide risk factors. When controlling for these factors, residual $\omega$ represents stock movements that are not accounted for by market portfolios and risks. Furthermore, since time-series correlation may occur in the residual, the conditional Fama French approach was applied to solve the problem (Luo 2009). The model is specified below:

$$
\omega_{i t}=\rho \omega_{i t-1}+\gamma_{i t} \cdots \cdots \cdots \cdots \cdots \cdots \cdot \text { Equation }
$$

where

$\gamma_{i t}=$ white noise (Luo 2009; McAlister, Srinivasan, and Kim 2007). 
Through this process, we derived weekly abnormal return values for the 71 firms covered in this study. Therefore, 18,460 observations were used (71 firms*5 years*52 weeks).

\subsubsection{Measure of NWOM}

In this study, we derived residual NWOM, which can minimize bias by controlling for firm, industry, and microeconomic factors (Luo 2009), to measure the clean NWOM for each firm.

To calculate residual NWOM, we used NWOM, firm, industry, and macroeconomic data. First, NWOM (dependent variable) was measured by the proportion of negative words to positive, negative, neutral, and other types of words in the online WOM posts that contain a firm's name. Second, we included firm-specific factors such as sales, news article volume, and news article valence. The volume of news articles was measured by the number of articles that mention the company name and the valence was measured by the proportion of negative words to positive, negative, neutral, and other types of words in the article in which the company was mentioned. We collected sales data from the KLCA and online WOM data from Socialmetrics. Third, we used the sales growth rate by industry as the industry-specific data. Firms were classified by the industry classification code provided by the KLCA, and the annual sales growth rate by industry was calculated and used. Lastly, we used the unemployment rate, the CPI, and GDP as macroeconomic factors, which were collected from Statistics Korea.

The model for finding residual NWOM using the variables explained above is as follows:

$$
\begin{aligned}
& N W O M_{i t}=\chi_{0} \\
& +\chi_{\text {firm-level }} \text { (Firm Characteristics) } \\
& +\chi_{\text {industry-level }} \text { (Industry Factors) } \\
& +\chi_{\text {macro-level }} \text { (Macro Indicators) } \\
& +\varepsilon_{i t} \\
& \text { Equation (3) }
\end{aligned}
$$

In this model, we used firm characteristics (sales, volume of news, and valence of news), industry factors (industry sales growth), and macroeconomic indicators (CPI and GDP). In Equation (3), $\varepsilon_{i t}$ corresponds to residual NWOM, which can be defined as unexpected NWOM after controlling for known factors such as firm, industry, and macroeconomic factors. To build a more precise NWOM variable, this study used residual NWOM (Luo 2009).

\subsubsection{Measures of CSR activities and $\mathrm{R} \& \mathrm{D}$ investment}

In this study, we analyzed how CSR activities and $R \& D$ investment influence the impact of NWOM on firm value. First, the measurement method of CSR is as follows. Donation expenditure is a significant part of CSR activities (Choi, Lee, and Hong 2009). Contribution expenditure 
reflects a significant proportion of CSR expenditure and has the advantage of being readily available from financial statements (Brown, Helland, and Smith 2006; Choi, Lee, and Hong 2009; Lev, Petrovits, and Radhakrishnan 2010; Lin, Yang, and Liou 2009; Shin, Kim, and Kim 2011). Since the size of the donation might vary depending on the size of the company, it was divided by sales (Choi, Lee, and Hong 2009; Lin, Yang, and Liou 2009; Shin, Kim, and Kim 2011). Second, the method used to measure the R\&D investment variables is as follows. In a number of studies of the impact of $\mathrm{R} \& \mathrm{D}$ investment on firm value, $\mathrm{R} \& \mathrm{D}$ expenditure divided by sales is used as the R\&D variable ( Gu 2016; Ho, Keh, and Ong 2005; Qiao, Fung, and Ju 2013; Seok, Kim, and Go 2019).

$\langle$ Table 1$\rangle$ describes the variables used in this study.

\subsection{Research Model}

To examine the effect of NWOM, we used the HLM, which is frequently employed in education studies as well as in other fields such as health, social work, and business (Woltman et al. 2012). Studies that have examined the impact of CSR activities on firm value and forecasted movie box-office performance have also used the HLM (Byun, Kim, and Nam 2013; Park, Chung, and Cho 2015). In some fields, HLMs are known as multilevel models and mixed level models (Woltman et al. 2012).

The HLM is a complex form of the ordinary least squares regression method that analyzes the variance in the outcome variable when the data are hierarchical (Woltman et al. 2012). Before the introduction of the HLM, fixed parameter regression was used to analyze hierarchical data, which is unsuitable because

$\langle$ Table 1〉 Measures and Sources of the Variables

\begin{tabular}{|c|c|c|}
\hline Variable & Description & Source \\
\hline $\begin{array}{l}\text { Abnormal Return } \\
(\mathrm{AR})\end{array}$ & $\begin{array}{l}\text { Abnormal return of each firm at time } t \\
\text { (weekly) }\end{array}$ & FnGuide \\
\hline $\begin{array}{l}\text { Corporate Social Responsibility } \\
\text { (CSR) }\end{array}$ & Donations scaled by sales (yearly) & \multirow{2}{*}{ KLCA } \\
\hline $\begin{array}{l}\text { Research and Development } \\
\text { (Research) }\end{array}$ & R\&D investment scaled by sales (yearly) & \\
\hline $\begin{array}{l}\text { Volume of Word of Mouth } \\
\text { (WOM_VOL) }\end{array}$ & $\begin{array}{l}\text { Volume of online posts for each firm at } \\
\text { time } t \text { (weekly) }\end{array}$ & \multirow[b]{2}{*}{ Socialmetrics } \\
\hline $\begin{array}{l}\text { Negative Word of Mouth } \\
(\text { NWOM) }\end{array}$ & $\begin{array}{l}\text { Negative word of mouth of each firm at time } \\
\mathrm{t} \text { (residual of negative word of mouth after } \\
\text { controlling firm, industry, and macroeconomic } \\
\text { factors) (weekly) }\end{array}$ & \\
\hline
\end{tabular}


it ignores shared variances (Woltman et al. 2012). For data that have a hierarchical structure, two problems can occur if the data's hierarchy is neglected (Byun, Kim, and Nam 2013). First, doing so may cause unnecessary errors since it is assumed that the units at the lower and upper levels are at the same level. Second, the influence of the higher level is neglected; thus, it is possible to assume that the coefficients are equal across all the levels in the regression model. Therefore, using the HLM, the influence of the lower-level variable can be measured more accurately, and cross-level interactions occurring between different levels can be analyzed (Hofmann 1997). Moreover, the HLM is more efficient than other methodologies for analyzing hierarchical data by simultaneously analyzing relationships such as those within and between hierarchical levels in grouped data (Woltman et al. 2012). Additionally, it can be used to analyze panel data (Byun, Kim, and Nam 2013; Snijders 1996).

In this study, the first level included weekly NWOM and the volume of WOM variable for each company, while the second level included each company's yearly CSR activities and R\&D investment. As a prerequisite for the cross-level analysis between firms before the hypothesis testing, an analysis of the variances between groups and their significance for abnormal returns (the dependent variable) was conducted through a null model, which is a model without independent variables at all the levels. As a result, abnormal returns showed a significant difference $(p<0.000)$ for each company.

The final analytical model used in this study is described in Equations (4), (5), and (6). The first-stage model examines the relationship between NWOM and abnormal returns (Hypothesis 1). The second stage tests Hypotheses 2 and 3 to examine whether the effects of NWOM appear differently or are influenced by the CSR activities and R\&D investment of each company. The distinct feature of this model is that it analyzes cross-level interactions using the coefficients of the lower stage as a dependent variable of the higher stage, unlike the ordinary least squares method (Byun, Kim, and Nam 2013).

First, the model at the first stage (level 1) is as follows:

$$
\begin{aligned}
& A R_{i j t}=\beta_{0 i j}+\beta_{1 i j} N W O M_{i j t} \\
& +\beta_{2 i j} W_{-} V O L_{i j t}+\beta_{3 i j} A R_{i j t-1}
\end{aligned}
$$

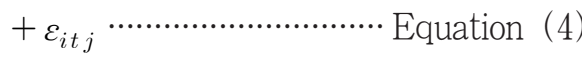

where

$A R_{i j t}$ is the abnormal return of firm $i$ in year $j$ at time $t$;

$A R_{i j t-1}$ is the abnormal return of firm $i$ in year $j$ at time $t-1$;

$W O M_{-} V O L_{i j t}$ is the volume of the WOM of firm $i$ in year $j$ at time $t$; and

$N W O M_{i j t}$ is the negativity of the WOM of firm $i$ in year $j$ at time $t$.

Second, the model at the second stage (level 
2) is as follows:

$$
\begin{aligned}
\beta_{0 i j}= & \gamma_{000}+\gamma_{001} C S R_{i j}+\gamma_{002} R E S E A R C H_{i j} \\
& +\eta_{0 i j} \cdots \cdots \cdots \cdots \cdots \cdots \cdots \cdots \cdots \cdots . \cdots \cdots
\end{aligned}
$$

$$
\begin{aligned}
& \beta_{1 i j}=\gamma_{100}+\gamma_{110} C S R_{i j}+\gamma_{120} R E S E A R C H_{i j}
\end{aligned}
$$

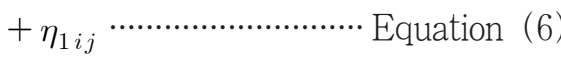

where

$C S R_{i j}$ is the CSR investment of firm $i$ in year $j$, and

RESEARCH $H_{i j}$ is the R\&D investment of firm $i$ in year $j$.

Equation (4) is a model at the first stage (level 1) that examines the effect of NWOM on abnormal returns. $\beta_{1 i j}$ is the core coefficient that indicates the effect of NWOM on abnormal returns. In addition, we used the volume of WOM for each company and abnormal returns in the prior period $(t-1)$ as control variables. Since this study's focus is on the influence of level 2 variables-CSR activities and R\&D investment-on the impact of NWOM on firm value, we only inputted level 2 variables in $\beta_{0 i j}$ and $\beta_{1 i j}$. Therefore, Equation (6) examines how the effect of NWOM on abnormal returns differs depending on the company's CSR activities and R\&D investment.

\section{Results}

\subsection{Descriptive Statistics}

〈Table 2〉 shows the descriptive statistics of the variables used in the analysis. The table includes the mean, standard deviation, minimum, and maximum values of the variables.

〈Table 3〉 shows the correlation coefficients of the key variables used in this study.

\subsection{Hypothesis Testing}

〈Table 4〉 presents the model's estimation results for testing the hypotheses. The model estimated 18,531 observations.

〈Table 2〉 Descriptive Statistics

\begin{tabular}{c|c|c|c|c}
\hline Variable & Mean & Standard Deviation & Min & Max \\
\hline \multicolumn{5}{c}{ Level 1 } \\
\hline AR & 0.002 & 5.274 & -39.75 & 126.053 \\
\hline WOM_VOL & 8.757 & 27.219 & 0 & 743.32 \\
\hline NWOM & $-2.56 \mathrm{E}-10$ & 0.116 & -0.628 & 0.943 \\
\hline \multicolumn{5}{c}{ Level 2 } \\
\hline RESEARCH & 0.001 & 0.003 & 0 & 0.027 \\
\hline
\end{tabular}


〈Table 3〉 Correlation Coefficients

\begin{tabular}{lccccc}
\hline & AR & WOM_VOL & NWOM & CSR & RESEARCH \\
\hline 1. AR & 1 & & & & \\
2. WOM_VOL & -.007 & 1 & & & \\
3. NWOM & -.015 & -.048 & 1 & & \\
4. CSR & .003 & .187 & -.026 & 1 & \\
5. RESEARCH & .004 & .119 & -.053 & .52 & 1 \\
\hline
\end{tabular}

〈Table 4〉 Parameter Estimates of the Model

\begin{tabular}{ccc}
\hline Variable & Coefficient & Standard Error \\
\hline$A R_{t-1}$ & Level 1 & \\
\hline WOM_VOL $(1000)$ & $-.045^{* * * *}$ & .007 \\
NWOM & -.002 & .002 \\
CONSTANT & $-1.301^{* * *}$ & .386 \\
\hline RESEARCH & .002 & .062 \\
\hline RESEARCH*NWOM & Level 2 & \\
CSR & .508 & 1.785 \\
CSR*NWOM & $22.741^{*}$ & 13.271 \\
& 8.261 & 24.645 \\
& 223.948 & 183.656 \\
\hline
\end{tabular}

$\aleph^{*}: \mathrm{p}<.1,{ }^{* *}: \mathrm{p}<.05,{ }^{* * *}: \mathrm{p}<.01$

First, when the negativity of WOM increased, $\quad$ affected abnormal returns $(\beta=22.741 ; \mathrm{p}<0.1)$. abnormal returns decreased $(\beta=-1.301 ; \mathrm{p}<$ As such, the third hypothesis is supported, and 0.01 ), even though the volume of WOM and we conclude that an increase in $R \& D$ investment abnormal returns (at $\mathrm{t}-1$ ) were controlled for. weakens the impact of NWOM on firm value. With this result, the first hypothesis is supported, and we conclude that NWOM negatively affects firm value. Next, CSR*NWOM had no significant effect on abnormal returns ( $\beta=$ 223.948; $p>0.1$ ). Therefore, the second hypothesis that an increase in CSR activity decreases the negative impact of NWOM on abnormal returns is not supported. Lastly, according to the estimation result, RESEARCH*NWOM significantly

\subsection{Additional Analysis ${ }^{1)}$}

\subsubsection{Different Roles of $R \& D$ Investment and CSR Activities in High-Tech and Non High-Tech Industries}

We have thus far found that the effect of NWOM on firm value differs according to R\&D

1) We thank the anonymous reviewers for suggesting this additional analysis 
investment and CSR activities, but this may depend on the industry to which the company belongs. Hence, based on the industry classification of the Korea Listed Companies Council, we divided the sample companies into 25 industry groups (see Table A-1 in the appendix).

We classified 10 industries with high R\&D investment as high-tech industries, in line with Simeth and Cincera (2016). Among the 71 sample companies, 21 are defined as high-tech companies. 〈Table 5〉 and $\langle$ Table 6$\rangle$ show the descriptive statistics.

Using the same model as in Equations (4) to (6), high-tech and non-high-tech companies were analyzed, as shown in $\langle$ Table 7$\rangle$.

The results show that NWOM negatively affects the firm value of both high-tech and non-high-tech companies. Notably, CSR activities in high-tech companies and R\&D investment in non-high-tech companies weaken the impact

〈Table 5〉 Description of High-Tech and Non-High-Tech Firms

\begin{tabular}{|c|c|c|c|c|}
\hline Variable & Mean & Standard Deviation & Min & Max \\
\hline \multicolumn{5}{|c|}{ High-Tech Industries } \\
\hline \multicolumn{5}{|c|}{ Level 1} \\
\hline $\mathrm{AR}$ & -0.082 & 5.273 & -39.75 & 38.361 \\
\hline WOM_VOL & $1,043.109$ & $2,230.344$ & 1 & 44,028 \\
\hline NWOM & -0.014 & 0.081 & -0.564 & 0.772 \\
\hline \multicolumn{5}{|c|}{ Level 2} \\
\hline CSR & 0.001 & 0.002 & 0 & 0.008 \\
\hline RESEARCH & 0.035 & 0.034 & 0 & 0.125 \\
\hline \multicolumn{5}{|c|}{ Non-High-Tech Industries } \\
\hline \multicolumn{5}{|c|}{ Level 1} \\
\hline $\mathrm{AR}$ & 0.038 & 5.274 & -37.015 & 126.053 \\
\hline WOM_VOL & 805.37 & $2,900.837$ & 0 & 74,332 \\
\hline NWOM & 0.006 & 0.128 & -0.628 & 0.943 \\
\hline \multicolumn{5}{|c|}{ Level 2} \\
\hline CSR & 0.001 & 0.003 & 0 & 0.027 \\
\hline RESEARCH & 0.01 & 0.032 & 0 & 0.272 \\
\hline
\end{tabular}

〈Table 6〉R\&D and CSR Expenditure of High-Tech and Non-High-Tech Industries

\begin{tabular}{c|c|c|c}
\hline & $\begin{array}{c}\text { AVG of R\&D } \\
\text { Investment } \\
\text { (million KRW) }\end{array}$ & $\begin{array}{c}\text { AVG of CSR } \\
\text { (million KRW) }\end{array}$ & Ratio of R\&D to CSR \\
\hline High-Tech & 211,665 & 6,606 & 0.031 \\
\hline Non-High-Tech & 6,669 & 1,350 & 0.202 \\
\hline
\end{tabular}


〈Table 7〉 Parameter Estimates of the Model (High-Tech and Non-High-Tech Firms)

\begin{tabular}{ccc}
\hline Industry & High-Tech & Non-High-Tech \\
\hline \multirow{2}{*}{ Variable } & $\begin{array}{c}\text { Coefficient } \\
\text { Standard Error) }\end{array}$ & $\begin{array}{c}\text { Coefficient } \\
\text { (Standard Error) }\end{array}$ \\
\hline \multirow{2}{*}{$A R_{t-1}$} & Level 1 & \\
\hline WOM_VOL $(1000)$ & $-.054^{* * * *}$ & $-.042^{* * * *}$ \\
& $(.013)$ & $(.009)$ \\
NWOM & -.002 & -.022 \\
& $(.04)$ & $(.02)$ \\
CONSTANT & $-3.533^{* *}$ & $-1.13^{* * *}$ \\
& $(1.547)$ & $(.41)$ \\
RESEARCH & -.253 & .047 \\
& $(.162)$ & $(.07)$ \\
\hline RESEARCH*NWOM & Level 2 & -.421 \\
& 4.383 & $(2.639)$ \\
CSR & $(3.022)$ & $32.376^{* *}$ \\
& 34.974 & $(16.418)$ \\
CSR*NWOM & $(30.04)$ & 11.132 \\
& 19.517 & $(30.514)$ \\
& $(61.91)$ & 32.044 \\
& $1092.993^{* *}$ & $(217.024)$ \\
\hline
\end{tabular}

$*^{*}: \mathrm{p}<.1, * *: \mathrm{p}<.05, * * *: \mathrm{p}<.01$

of NWOM. In general, high-tech companies use a large amount of resources for $R \& D$ (Simeth and Cincera 2016). For this reason, stakeholders expect high-tech companies to spend a considerable amount on R\&D. Therefore, for high-tech companies to invest more in R\&D to increase firm value, the marginal effect is relatively small. On the contrary, in the case of CSR activities, the marginal effect of improving firm value is relatively large for tech-savvy companies as people do not expect companies to conduct a large number of CSR activities. In other words, tech-savvy companies can raise their reputation by unexpectedly being socially responsible. This is in line with the finding that high-tech companies increase their firm image and economic performance through CSR activities (Chang 2009). Meanwhile, R\&D investment in non-high-tech companies has a positive effect on product innovation (Hervas-Oliver, Garrigos, and Gil-Pechuan 2011). In addition, the more non-high-tech companies invest in $\mathrm{R} \& \mathrm{D}$, the more they can accumulate $R \& D$ knowledge that makes a marginal contribution, which improves firm performance (Booltink and Saka-Helmhout 2018). Further, as shown in 〈Table 6〉, since 
〈Table 8〉 Parameter Estimates of the Model with PWOM

\begin{tabular}{ccc}
\hline Variable & Coefficient & Standard Error \\
\hline & Level 1 & \\
\hline$A R_{t-1}$ & $-.045^{* * * *}$ & .007 \\
WOM_VOL (1000) & -.002 & .002 \\
PWOM & $.894^{* * *}$ & .253 \\
CONSTANT & -.009 & .063 \\
\hline RESEARCH & Level 2 & 1.891 \\
RESEARCH*PWOM & .443 & 10.740 \\
CSR & -2.309 & 26.476 \\
CSR*PWOM & 18.386 & 136.819 \\
\hline
\end{tabular}

non-high-tech companies have lower R\&D investment than high-tech companies, consumers may perceive that their expertise is relatively low. Therefore, the negative impact of NWOM may be alleviated by giving consumers the perception that the company is increasing its expertise through R\&D investment.

$$
\begin{aligned}
& \alpha_{o i j}=\delta_{000}+\delta_{001} C S R_{i j} \\
& +\delta_{002} R E S E A R C H_{i j}+\rho_{0 i j} \\
& \text { Equation (8) } \\
& \alpha_{1 i j}=\delta_{100}+\delta_{110} C S R_{i j} \\
& +\delta_{120} R E S E A R C H_{i j}+\rho_{1 i j}
\end{aligned}
$$

\subsubsection{Positive Effect of PWOM}

Further analysis was conducted to analyze the effect of PWOM on firm value, as shown in $\langle$ Table 8$\rangle$. PWOM was calculated using the same method as in Equation (3). The full model is specified below:

$$
\begin{aligned}
& A R_{i j t}=\alpha_{0 i j}+\alpha_{1 i j} P W O M_{i j t} \\
& +\alpha_{2 i j} W_{-} O M_{-} O L_{i j t}+\alpha_{3 i j} A R_{i j t-1}
\end{aligned}
$$

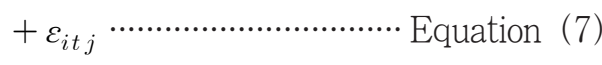

While this study focuses on the effect of NWOM on firm value, various studies have addressed the effect of both PWOM and NWOM (Chevalier and Mayzlin 2006; Liu 2006; Nguyen, Calantone, and Krishnan 2020). According to Chevalier and Mayzlin (2006), negative reviews have a greater impact because consumers know that while stakeholders can elicit large amounts of positive reviews relatively easily, negative reviews cannot be prevented. Therefore, in this study, not only the effects of NWOM but 
also the effects of PWOM were additionally analyzed. The results show that PWOM increases firm value, with the influence of NWOM greater than that of PWOM $\left(\left|\beta_{1 i j}\right|=|-1.301|>\right.$ $\left.\alpha_{1 i j}=0.894\right)$. According to Nguyen, Calantone, and Krishnan's (2020) study of the impact of WOM in social media on investors decisionmaking and firm value, PWOM increases investment and enterprise value because positive sentiment is revealed when performance is higher than expected, which in turn raises future sales and profits (Nguyen, Calantone, and Krishnan 2020; Oliver et al. 1997; Tuli and Bharadwaj 2009; Rychalski and Hudson 2017). In short, PWOM increases firm value, while NWOM decreases it and the influence is stronger for NWOM.

\section{Discussion and Conclusion}

This study examined the effect of NWOM on firm value. It found that NWOM has a significant negative effect on firm value. In other words, we can conclude that as the negativity of WOM increases, firm value decreases. This is in line with previous studies of the effect of NWOM on firm value (Luo 2007; Luo 2009; Nguyen, Calantone, and Krishnan 2020).

According to the results of the analysis, the influence of CSR activities on the impact of
NWOM on firm value is not significant. Therefore, the second hypothesis that as CSR activities increase, the impact of NWOM on firm value decreases is not supported. There are three possible explanations for this result.

First, consumers who witness the coexistence of CSR and NWOM in a firm may regard the CSR activities conducted by the firm as hypocritical. CSR is known to have a positive impact on society and the environment (Porter and Kramer 2006). Wagner, Lutz, and Weitz (2009) defined corporate hypocrisy as the "belief that a firm claims to be something that it is not," and in general, people detect hypocrisy when there is a distance between a firm's assertion and actual performance (Shklar 1984). The CSR beliefs of consumers are a comprehensive assessment of how socially responsible a company is (Du, Bhattacharya, and Sen 2007), and CSR beliefs and attitudes toward the company are largely determined by accessing information on CSR (Brown and Dacin 1997; Sen, Bhattacharya, and Korschun 2006). According to Chen et al. (2020), the coexistence of CSR and corporate social irresponsibility (CSI) causes consumers to feel hypocrisy strongly. Moreover, the detection of hypocrisy from a company negatively affects consumers' CSR beliefs and brand attitudes (Wagner, Lutz, and Weitz 2009). When consumers come across NWOM, they tend to attribute the cause to objects such as the company (Hilton and Jaspars 1987). In short, even if CSR activities increase intangible assets such as 
brand image, reputation, and loyalty, when consumers encounter NWOM simultaneously, they detect hypocrisy, as they attribute the cause of NWOM to the company. Therefore, we can infer that CSR activities do not reduce the negative impact of NWOM. The results from the further analysis suggest that consumers sense corporate hypocrisy when they feel a gap between the warm feeling of CSR activities and negative image of the company, such as corporate social irresponsibility. Because hightech companies manufacture products that consumers use, since WOM about these companies is more likely to be about products and technologies than the firm image itself, there is a high possibility that corporate hypocrisy will not occur.

Second, the measurement of the CSR activities variable used in this study is limited. In this study, donation was set as a proxy variable for CSR, following previous studies that have argued that donations are appropriate for measuring CSR activities (Brown, Helland, and Smith 2006: Choi, Lee, and Hong 2009; Lev, Petrovits, and Radhakrishnan 2010; Lin, Yang, and Liou 2009: Shin, Kim, and Kim 2011). According to Carroll (1979), CSR can be divided into economic, legal, ethical, and philanthropic responsibilities, and each of these multidimensional responsibilities can be highlighted differently depending on the time and situation. Based on this logic, difficulties might exist when defining CSR activities based only on donations. In other words, since the CSR activities of a company as perceived by consumers do not comprise only donations, the effect of CSR may have been measured incorrectly.

Third, consumers tend to evaluate competence as being more important than warmth when choosing a company. In this study, we raised the possibility of a linkage between CSR activities and warmth. From the SCM perspective, warmth includes factors such as kindness, friendliness, and morality (Cuddy, Fiske, and Glick 2008). According to Kirmani et al. (2017), when consumers evaluate a firm, there is a trade-off between morality and competence, and competence is considered to be more crucial than morality. In other words, the ability of a company to achieve its goals is evaluated higher than the ethical aspect because consumers pay little attention to moral violations in achieving a goal (Kirmani et al. 2017). Based on this logic, if consumers expect companies to achieve their goals and if CSR activities such as donations are not directly felt by them, the effect of the warmth aspect would be smaller than the competence aspect. Therefore, CSR investments do not reduce the impact of NWOM on firm value.

In this study, $R \& D$ investments were found to reduce the negative impact of NWOM on abnormal returns significantly. Therefore, our third hypothesis that an increase in R\&D investment decreases the negative impact of NWOM on firm value is supported. In other 
words, as companies increase their R\&D investment, they can reduce the negative impact of NWOM. The interpretation is as follows. Unlike CSR activities such as donations, R\&D investment helps develop the capabilities of a company and achieve its goal; thus, it is unlikely that corporate hypocrisy is detected by consumers even if they experience NWOM. In addition, NWOM is said to decrease intangible assets such as customer and brand equity (Srivastaba, Shervani, and Fahey 1998) and dilute brand equity (Bambauer-Sachse and Mangold 2011). However, as the amount of $\mathrm{R} \& \mathrm{D}$ investment increases, brand equity increases (Smith, Gradojevic, and Irwin 2007). Peterson and Jeong (2010) argued that R\&D investment enhances brand value, which is also an intangible asset. Therefore, according to the logic of these previous studies, companies can increase intangible assets by investing in R\&D, which weakens the negative impact of NWOM. In this study, we raised the possibility of a linkage between $R \& D$ investment and competence since some studies have argued that R\&D expenditure could be a proxy variable for technical competence because the accumulation of technological experience through R\&D efforts contributes to the development of technological capacity (Kocoglu et al. 2012; Lee 2011). Competence enhances intangible assets such as customer loyalty, purchase intention, and consumer satisfaction (Balqiah 2018; Gao and Mattila 2014; Kervyn, Fiske, and Malone 2012).
Therefore, since NWOM negatively influences firm value by decreasing intangible assets, an increase in competence can offset this impact.

This study makes several academic contributions. First, we empirically examined the effect of NWOM on firm value. In particular, by analyzing a relatively large dataset containing 18,531 observations from 71 companies for five years, the effect was precisely measured.

Second, we confirmed that the HLM can be applied in empirical studies by implementing it on panel data. Using the HLM allows researchers to measure the influence of lower-level variables accurately and check the cross-level interactions between levels (Hofmann 1997). Hence, using the HLM as a model in this study, we examined the impact of NWOM on each company's value rather than looking at all of them as a whole and discussed how that influence depends on the company's CSR activities and R\&D investment.

Third, we raised the possibility of implementing the concept of the SCM on firms' features. SCM theory suggests that humans make judgments using two criteria, namely, warmth and competence, when evaluating other people and groups. This theory has been mainly applied at the individual level. This study differs from other studies in that although we did not define warmth and competence as a firm's specific attributes, we raised the possibility of linking them with CSR activities and R\&D investment. This study's empirical findings have several 
practical implications. First, companies must prevent and manage NWOM. With the spread of mobile devices and high-speed Internet, consumers can access social media platforms anytime, anywhere. This makes it easier for them to listen to others and share their opinions. Therefore, it has become common for consumers to exchange information related to companies. In this study, we confirmed that NWOM decreases firm value, as measured by stock returns. This implies that companies must devise various ways to listen to and manage customers' voice.

Second, if NWOM occurs because of unavoidable events, the findings of this research suggest that companies can reduce the impact of NWOM by improving their competitiveness, for instance, by investing in R\&D and communicating this to their consumers. This is in line with the findings of previous research that firm value can be enhanced quickly through active R\&D investment and by informing consumers about such investments (Seok, Kim, and Go 2019).

Lastly, it is possible to increase a company's intangible assets through R\&D investment. NWOM is said to affect firm value negatively by decreasing intangible assets such as customer and brand equity (Bambauer-Sachse and Mangold 2011; Luo 2009; Srivastaba, Shervani, and Fahey 1998). In this study, the results suggest that an increase in $R \& D$ investment reduces the negative impact of NWOM. This finding signifies that $R \& D$ investment reduces the impact of NWOM by increasing the intangible assets of a firm. This interpretation is in line with previous studies that find that intangible assets such as brand equity and brand evaluation can be increased through R\&D investment (Peterson and Jeong 2010; Smith, Gradojevic, and Irwin 2007).

Regardless of its various contributions, this study has several limitations. First, the sample is limited to Korean companies, which makes it difficult to generalize the results beyond the Korean context. In addition, the 71 companies used in this study are those listed in the KMAC report. Since firms listed in the KMAC report are likely to be relatively large and well-known companies, there may be difficulties in generalizing the results. If research is conducted on various nations and includes small companies in the future, this may provide more generalized implications on the role of CSR activities and R\&D investment in the relationship between NWOM and firm value.

Second, examining which firm-level factors correspond to the warmth and competence of a company can contribute to SCM research. In this study, we raised the possibility that CSR activities and R\&D investment may be related to the warmth and competence of a company (Chen et al. 2020; Kocoglu et al. 2012; Lee 2011; Shea and Hawn 2019). In particular, this study measured CSR activities as the amount of donations based on previous studies. However, 
companies conduct CSR not only through donations, but also through volunteer activities, employee welfare improvement, and responsible management. Therefore, solely focusing on donations may not reflect the overall CSR activities of a company.

Third, people can judge a firm by various criteria other than competence and warmth, such as image, reliability, and fairness. These attributes of companies can be investigated through surveys and experiments. However, we could not include the various images of companies in this study since we analyzed quantitative variables that can be observed for a relatively long period by constructing longitudinal data. Expanding our model by developing a method to investigate the various images of companies would allow future research to examine the relationship between WOM and firm value more in depth.

Finally, this study did not include variables such as advertising costs. In traditional marketing research, advertising expenditure has been treated as an important variable influencing firm performance. However, most of the advertising expenses disclosed by companies are limited to the products they produce. This is different from CSR activities and R\&D investments that are expected to affect the intangible assets of companies. If it was possible to measure advertising expenses that enhance the image of a company, it would be consistent with the goal of this study. However, it is difficult to measure such a variable because advertising expenses that enhance the firm image are not separately disclosed. If a method to measure company-wide advertising and public relations costs became available, this would help companies devise strategies to cope with NWOM.

〈Received July 31. 2020〉 〈Accepted October 12. 2020〉

\section{References}

Babić Rosario, A., Sotgiu, F., De Valck, K., \& Bijmolt, T. H. (2016). The effect of electronic word of mouth on sales: A meta-analytic review of platform, product, and metric factors. Journal of Marketing Research, 53(3), 297-318.

Balqiah, T. E. (2018). Green CSR and brand attitude: the role of stereotype content model. European Research Studies Journal, 21(1), 230-249

Bambauer-Sachse, S., \& Mangold, S. (2011). Brand equity dilution through negative online word-of-mouth communication. Journal of Retailing and Consumer Services, 18 (1), 38-45.

Baron, D. P. (2009). A positive theory of moral management, social pressure, and corporate social performance. Journal of Economics \& Management Strategy, 18(1), 7-43.

Blodgett, J. G., \& Li, H. (2007). Assessing the 
effects of post-purchase dissatisfaction and complaining behavior on profitability: a monte carlo simulation. Journal of Consumer Satisfaction, Dissatisfaction and Complaining Behavior, 20, 1.

Booltink, L. W., \& Saka-Helmhout, A. (2018). The effects of R\&D intensity and internationalization on the performance of non-high-tech SMEs. International Small Business Journal, 36(1), 81-103.

Brown, T. J., \& Dacin, P. A. (1997). The company and the product: Corporate associations and consumer product responses. Journal of Marketing, 61(1), 68-84.

Brown, W. O., Helland, E., \& Smith, J. K. (2006). Corporate philanthropic practices. Journal of Corporate Finance, 12(5), 855877.

Byun, S. M., Kim, J. H., \& Nam, I. W. (2013). Long Term Effect of Corporate Social Responsibility Activities on Firm Value Accounting for Marketing and Industry Factors. Korean Management Review, 42 (5), 1289-1313

Carroll, A. B. (1979). A three-dimensional conceptual model of corporate performance. Academy of Management Review, 4(4), 497-505.

Carroll, A. B., \& Shabana, K. M. (2010). The business case for corporate social responsibility: A review of concepts, research and practice. International Journal of Management Reviews, 12(1), 85-105.
Chakravarty, A., \& Grewal, R. (2011). The stock market in the driver's seat! Implications for R\&D and marketing. Management Science, 57(9), 1594-1609.

Chang, C. P. (2009). The relationships among corporate social responsibility, corporate image and economic performance of hightech industries in Taiwan. Quality and Quantity, 43(3), 417.

Chen, Z., Hang, H., Pavelin, S., \& Porter, L. (2020). Corporate Social (Ir)responsibility and Corporate Hypocrisy: Warmth, Motive and the Protective Value of Corporate Social Responsibility. Business Ethics Quarterly, 1-39. doi:10.1017/beq.2019.50

Chevalier, J. A., \& Mayzlin, D. (2006). The effect of word of mouth on sales: Online book reviews. Journal of Marketing Research, 43(3), 345-354.

Choi, B., \& La, S. (2013). The impact of corporate social responsibility (CSR) and customer trust on the restoration of loyalty after service failure and recovery. Journal of Services Marketing, 27(3), 223-233

Choi, W. Y., Lee, H. S., \&Hong, C. S. (2009). Corporate Social Responsibility and Firm Value: Focused on Corporate Contributions, Korean Management Review, 38(2), 407432

Cuddy, A. J., Fiske, S. T., \& Glick, P. (2008). Warmth and competence as universal dimensions of social perception: The stereotype content model and the BIAS 
map. Advances in Experimental Social Psychology, 40, 61-149.

Cuddy, A. J., Glick, P., \& Beninger, A. (2011). The dynamics of warmth and competence judgments, and their outcomes in organizations. Research in Organizational Behavior, 31, 73-98.

Del Monte, Alfredo and Erasmo Papagni (2003), "R\&D and the growth of firms: empirical analysis of a panel of Italian firms," Research Policy, 32(6), 1003-1014.

Du, S., Bhattacharya, C. B., \& Sen, S. (2007). Reaping relational rewards from corporate social responsibility: The role of competitive positioning. International Journal of Research in Marketing, 24(3), 224-241.

Durante, F., Volpato, C., \& Fiske, S. T. (2010). Using the Stereotype Content Model to examine group depictions in Fascism: An archival approach. European Journal of Social Psychology, 40(3), 465-483.

Eberhart, A. C., Maxwell, W. F., \& Siddique, A. R. (2004). An examination of long-term abnormal stock returns and operating performance following $R \& D$ increases. The Journal of Finance, 59(2), 623-650.

Fama, E. F., \& French, K. R. (1993). Common risk factors in the returns on stocks and bonds. Journal of Financial Economics, 33 (1), 3-56

Fama, E. F., \& French, K. R. (2006). The value premium and the CAPM. The Journal of Finance, 61(5), 2163-2185.
Fiske, S. T., Cuddy, A. J., \& Glick, P. (2007). Universal dimensions of social cognition: Warmth and competence. Trends in Cognitive Sciences, 11(2), 77-83.

Fiske, S. T., Xu, J., Cuddy, A. C., \& Glick, P. (1999). (Dis) respecting versus (dis) liking: Status and interdependence predict ambivalent stereotypes of competence and warmth. Journal of Social Issues, 55(3), 473-489.

Fournier, S. (1998). Consumers and their brands: Developing relationship theory in consumer research. Journal of Consumer Research, 24(4), 343-373.

Gao, Y. L., \& Mattila, A. S. (2014). Improving consumer satisfaction in green hotels: The roles of perceived warmth, perceived competence, and CSR motive. International Journal of Hospitality Management, 42, 20-31.

Gu, L. (2016). Product market competition, R\&D investment, and stock returns. Journal of Financial Economics, 119(2), 441-455.

Gupta, S., \& Zeithaml, V. (2006). Customer metrics and their impact on financial performance. Marketing Science, 25(6), 718-739.

Handelman, J. M., \& Arnold, S. J. (1999). The role of marketing actions with a social dimension: Appeals to the institutional environment. Journal of Marketing, 63(3), 33-48.

Hervas-Oliver, J. L., Garrigos, J. A., \& GilPechuan, I. (2011). Making sense of innovation 
by $R \& D$ and non-R\&D innovators in low technology contexts: A forgotten lesson for policymakers. Technovation, 31(9), 427446.

Hilton, D. J., \& Jaspars, J. M. (1987). The explanation of occurrences and nonoccurrences: A test of the inductive logic model of causal attribution. British Journal of Social Psychology, 26(3), 189-201.

Ho, Y. K., Keh, H. T., \& Ong, J. M. (2005). The effects of $R \& D$ and advertising on firm value: An examination of manufacturing and nonmanufacturing firms. IEEE Transactions on Engineering Management, 52(1), 3-14.

Hofmann, D. A. (1997). An overview of the logic and rationale of hierarchical linear models. Journal of Management, 23(6), 723-744.

Jeon, J., Lim, T., Kim, B. D., \& Seok, J. (2019). Effect of Online Word of Mouth on Product Sales: Focusing on Communication-Channel Characteristics. Asia Marketing Journal, 21(2), 73-98.

Jones, T. M. (1995). Instrumental stakeholder theory: A synthesis of ethics and economics. Academy of Management Review, 20(2), 404-437.

Kervyn, N., Fiske, S. T., \& Malone, C. (2012). Brands as intentional agents framework: How perceived intentions and ability can map brand perception. Journal of Consumer Psychology, 22(2), 166-176.
Kim, B.D. (2016). Core Management Theory and Practice. Seoul, hainaim

Kirmani, A., Hamilton, R. W., Thompson, D. V., \& Lantzy, S. (2017). Doing well versus doing good: The differential effect of underdog positioning on moral and competent service providers. Journal of Marketing, 81 (1), 103-117.

Kocoglu, I., Imamoglu, S. Z., Ince, H., \& Keskin, H. (2012). Learning, R\&D and manufacturing capabilities as determinants of technological learning: enhancing innovation and firm performance. Procedia-social and Behavioral Sciences, 58, 842-852.

Laczniak, R. N., DeCarlo, T. E., \& Ramaswami, S. N. (2001). Consumers' responses to negative word-of-mouth communication: An attribution theory perspective. Journal of Consumer Psychology, 11(1), 57-73.

Lee, C. Y. (2011). The differential effects of public R\&D support on firm R\&D: Theory and evidence from multi-country data. Technovation, 31(5-6), 256-269.

Lee, Y. J. (2019). Service Marketing. Paju, Hakhyunsa

Lev, B., Petrovits, C., \& Radhakrishnan, S. (2010). Is doing good good for you? How corporate charitable contributions enhance revenue growth. Strategic Management Journal, 31(2), 182-200.

Li, X., Chan, K. W., \& Kim, S. (2019). Service with emoticons: How customers interpret employee use of emoticons in online service 
encounters. Journal of Consumer Research, 45(5), 973-987.

Lin, B. W., Lee, Y., \& Hung, S. C. (2006). R\&D intensity and commercialization orientation effects on financial performance. Journal of Business Research, 59(6), 679-685.

Lin, C. H., Yang, H. L., \& Liou, D. Y. (2009). The impact of corporate social responsibility on financial performance: Evidence from business in Taiwan. Technology in Society, 31(1), 56-63.

Liu, Y. (2006). Word of mouth for movies: Its dynamics and impact on box office revenue. Journal of Marketing, 70(3), 74-89.

Luo, X. (2007). Consumer negative voice and firm-idiosyncratic stock returns. Journal of Marketing, 71(3), 75-88.

Luo, X. (2009). Quantifying the long-term impact of negative word of mouth on cash flows and stock prices. Marketing Science, 28(1), 148-165.

Mahajan, V., Muller, E., \& Kerin, R. A. (1984). Introduction strategy for new products with positive and negative word-of-mouth. Management Science, 30(12), 1389-1404. Martínez, P., \& Del Bosque, I. R. (2013). CSR and customer loyalty: The roles of trust, customer identification with the company and satisfaction. International Journal of Hospitality Management, 35, 89-99.

McAlister, L., Srinivasan, R., \& Kim, M. (2007). Advertising, research and development, and systematic risk of the firm. Journal of
Marketing, 71(1), 35-48.

Mizik, N., \& Jacobson, R. (2003). Trading off between value creation and value appropriation: The financial implications of shifts in strategic emphasis. Journal of Marketing, 67(1), 63-76.

Neelamegham, R., \& Jain, D. (1999). Consumer choice process for experience goods: An econometric model and analysis. Journal of Marketing Research, 36(3), 373-386.

Nguyen, H., Calantone, R., \& Krishnan, R. (2020). Influence of social media emotional word of mouth on institutional investors' decisions and firm value. Management Science, 66 (2), 887-910.

Park, J., Chung, Y., \& Cho, Y. (2015). Using the hierarchical linear model to forecast movie box-office performance: The effect of online word of mouth. Asia Pacific Journal of Information Systems, 25(3), 563-578.

Pava, M. L., \& Krausz, J. (1996). The association between corporate social-responsibility and financial performance: The paradox of social cost. Journal of Business Ethics, 15 (3), 321-357.

Peterson, R. A., \& Jeong, J. (2010). Exploring the impact of advertising and $R \& D$ expenditures on corporate brand value and firm-level financial performance. Journal of the Academy of Marketing Science, 38 (6), 677-690.

Porter, M. E., \& Kramer, M. R. (2006). The 
link between competitive advantage and corporate social responsibility. Harvard Business Review, 84(12), 78-92.

Qiao, P., Fung, H. G., \& Ju, X. (2013). Effects of social capital, top executive attributes and $R \& D$ on firm value in Chinese small and medium-sized enterprises. China \& World Economy, 21(4), 79-100.

Rust, R. T., Lemon, K. N., \& Zeithaml, V. A. (2004). Return on marketing: Using customer equity to focus marketing strategy. Journal of Marketing, 68(1), 109-127.

Schwartz, M. S., \& Carroll, A. B. (2003). Corporate social responsibility: A threedomain approach. Business Ethics Quarterly, 503-530.

Sen, S., Bhattacharya, C. B., \& Korschun, D. (2006). The role of corporate social responsibility in strengthening multiple stakeholder relationships: A field experiment. Journal of the Academy of Marketing Science, 34(2), 158-166.

Seok, J. H., Kim, B. D., \& Go, S. R. (2019). Impact of $R \& D$ Investment on Firm Value: The Role of Customer Awareness. Journal of Consumer Studies, 30(1), 43-67 Seok, J. H., Lee, Y. S., Go, S. R., \& Kim, B. D. (2017). Impact of Publicizing Corporate Social Responsibility on Firm Value. Korean Management Review, 46(6), 1663-1688

Servaes, H., \& Tamayo, A. (2013). The impact of corporate social responsibility on firm value: The role of customer awareness.
Management science, 59(5), 1045-1061. Shea, C. T., \& Hawn, O. V. (2019). Microfoundations of corporate social responsibility and irresponsibility. Academy of Management Journal, 62(5), 1609-1642.

Shin, M. S., Kim, S. E., \& Kim, B. S. (2011). The Effects of Corporate Social Responsibility Expenditure on Firm Value, Financial Engineering Studies, 10(1), 99-125

Shklar, J. N. (1984). Ordinary vices. Harvard University Press.

Simeth, M., \& Cincera, M. (2016). Corporate science, innovation, and firm value. Management Science, 62(7), 1970-1981.

Singh, J. (1988). Consumer complaint intentions and behavior: definitional and taxonomical issues. Journal of Marketing, 52(1), 93-107.

Smith, D. J., Gradojevic, N., \& Irwin, W. S. (2007). An analysis of brand equity determinants: Gross profit, advertising, research, and development. Journal of Business \& Economics Research (JBER), 5(11).

Snijders, T. (1996). Analysis of longitudinal data using the hierarchical linear model. Quality and Quantity, 30(4), 405-426.

Sridhar, S., Narayanan, S., \& Srinivasan, R. (2014). Dynamic relationships among R\&D, advertising, inventory and firm performance. Journal of the Academy of Marketing Science, 42(3), 277-290.

Srivastava, R. K., Shervani, T. A., \& Fahey, L. (1998). Market-based assets and shareholder 
value: A framework for analysis. Journal of Marketing, 62(1), 2-18.

Sun, M. (2012). How does the variance of product ratings matter?. Management Science, 58(4), 696-707.

Van Hoye, G., \& Lievens, F. (2007). Social Influences on Organizational Attractiveness: Investigating If and When Word of Mouth Matters 1. Journal of Applied Social Psychology, 37(9), 2024-2047.
Wagner, T., Lutz, R. J., \& Weitz, B. A. (2009). Corporate hypocrisy: Overcoming the threat of inconsistent corporate social responsibility perceptions. Journal of Marketing, 73(6), 77-91.

Woltman, H., Feldstain, A., MacKay, J. C., \& Rocchi, M. (2012). An introduction to hierarchical linear modeling. Tutorials in Quantitative Methods for Psychology, 8 (1), 52-69. 


\section{Appendix}

$\langle$ Table A-1 $\rangle$ Types of Industries Used in the Model

\begin{tabular}{|c|c|c|c|}
\hline Industry & Type & Frequency & Percent \\
\hline Fabricated Metal Product Manufacturing & \multirow{9}{*}{$\begin{array}{l}\text { High- } \\
\text { Tech }\end{array}$} & 1 & 1.41 \\
\hline Rubber and Plastic Product Manufacturing & & 2 & 2.82 \\
\hline Machinery and Equipment Manufacturing & & 1 & 1.41 \\
\hline Transportation Equipment Manufacturing & & 3 & 4.23 \\
\hline Medical Material and Drug Medicine Manufacturing & & 4 & 5.63 \\
\hline Automobile and Trailer Manufacturing & & 3 & 4.23 \\
\hline Electric Device Manufacturing & & 1 & 1.41 \\
\hline $\begin{array}{l}\text { Electric Parts, Computer, Video, Sound, and Telecommunication } \\
\text { Equipment Manufacturing }\end{array}$ & & 2 & 2.82 \\
\hline Chemical Substance and Chemical Product Manufacturing & & 4 & 5.63 \\
\hline Educational Services Industry & \multirow{16}{*}{$\begin{array}{l}\text { Non- } \\
\text { High- } \\
\text { Tech }\end{array}$} & 2 & 2.82 \\
\hline Wholesale and Commodities Brokerage & & 4 & 5.63 \\
\hline Broadcasting Industry & & 1 & 1.41 \\
\hline Non-Metallic Minerals Product Manufacturing & & 4 & 5.63 \\
\hline Business Support Service & & 4 & 5.63 \\
\hline Textile Product Manufacturing & & 3 & 4.23 \\
\hline Retail Business (Automobile Excluded) & & 2 & 2.82 \\
\hline Groceries Manufacturing & & 10 & 14.08 \\
\hline Post and Networking Business & & 3 & 4.23 \\
\hline Land Transportation and Pipeline Transportation & & 1 & 1.41 \\
\hline Clothes, Accessories, and Fur Piece Manufacturing & & 3 & 4.23 \\
\hline Electricity, Gas, Steam and Air Conditioning Supply Business & & 2 & 2.82 \\
\hline Specialized Service Industry & & 3 & 4.23 \\
\hline General Construction Business & & 4 & 5.63 \\
\hline Cokes, Briquette, and Oil Refined Product Manufacturing & & 2 & 2.82 \\
\hline Pulp, Paper, and Paper Product Manufacturing & & 2 & 2.82 \\
\hline Total & & 71 & 100 \\
\hline
\end{tabular}

